\title{
Latitudinal variability in phosphate uptake in the Central Atlantic
}

\author{
Mireia Cañellas*, Susana Agustí, Carlos M. Duarte** \\ Instituto Mediterráneo de Estudios Avanzados (IMEDEA), CSIC-Universitat de Illes Balears, \\ c/Miquel Marquès 21, 07190 Esporles (Illes Balears), Spain
}

\begin{abstract}
The role of $\mathrm{P}$ in regulating planktonic production in Atlantic waters was assessed by the examination of the phosphate turnover time and uptake rate along a latitudinal transect across the Central Atlantic Ocean $\left(27^{\circ} \mathrm{N}\right.$ to $\left.36^{\circ} \mathrm{S}\right)$. Phosphate uptake rates and the affinity for phosphate were higher for small $(<0.8 \mu \mathrm{m})$ organisms, compared with those $>0.8 \mu \mathrm{m}$. Phosphate uptake rates were relatively low, resulting in long phosphate turnover times (days), except in the surface waters south of $25^{\circ} \mathrm{S}$, which were also characterized by the highest uptake rates and affinity for phosphate, and the smallest total $P$ pools observed along the transect. The organisms were found to realize their maximal phosphate uptake rates at ambient phosphate concentrations, suggesting the adequacy of the $P$ supply to support the requirements of organisms. These findings suggest that inorganic $P$ was not limiting community production in most of the Central Atlantic, except for the area south of $25^{\circ} \mathrm{S}$, where $\mathrm{P}$ uptake could possibly be limited by $\mathrm{P}$ supply. The long turnover times generally observed in the Central Atlantic Ocean are in agreement with previous observations in oceanic systems elsewhere, suggesting that the observation that $P$ is unlikely to be a limiting resource for planktonic growth can be extrapolated to most of the open ocean. The combined rate of $P$ excretion from planktonic organisms and their microbial grazers as dissolved organic phosphorus (DOP) represented $75 \%$ of the total phosphate uptake. This DOP does not reach a sufficient accumulation as to drive an important downward flux of DOP, which represents a loss of only $9 \%$ of the $\mathrm{P}$ inputs into the biogenic layer. Hence, the high $\mathrm{P}$ uptake rate of the planktonic community in the Central Atlantic provides $\mathrm{P}$ in excess to support primary production, leading to a release as DOP, which appears to be rapidly recycled in the biogenic layer, thereby maintaining an adequate $P$ supply to fuel primary production.
\end{abstract}

KEY WORDS: Phosphate - Uptake · Atlantic · Excretion · Turnover · Picoplankton - Microplankton

\section{INTRODUCTION}

The quantification of the uptake of phosphorus by oceanic plankton has received limited attention (e.g. Carpenter \& Capone 1983) relative to the dominant interest in nitrogen, the element most frequently limiting marine production (Downing 1999). Even if the belief that $\mathrm{P}$ does not play a limiting role in the ocean is correct, knowledge of the phosphorus uptake by plankton is needed to effectively model the biogeochemical cycling of $P$, which has been suggested to exert an important control on the long-term changes in

\footnotetext{
- Present address: Regidoria de Medi Ambient i Sostenibilitat, Ajuntament de Sabadell, C. del Sol 1-1, 08201 Sabadell, Spain

-Corresponding author. E-mail: ieacdq@clust.uib.es
}

the production of the oceans (Redfield 1958, Broecker 1982). While $\mathrm{N}$ limitation has only been demonstrated for autotrophs, P limitation has been demonstrated for both marine autotrophic (e.g. Smith 1984, Krom et al. 1992, Thingstad \& Rassoulzadegan 1995, Thingstad et al. 1998) and heterotrophic plankton (e.g. Cotner et al. 1997, Rivkin \& Anderson 1997, Thingstad et al. 1998). Moreover, available information points to a prominent role of picoplankton, both autotrophic and heterotrophic, on P uptake (Currie \& Kalff 1984, Bratbak \& Thingstad 1985, Vadstein et al. 1993). Because these organisms are important contributors to the plankton biomass of the tropical ocean (e.g. Gasol et al. 1997), they may be hypothesized to play a dominant role in the cycling of $P$ within the biogenic layer there.

The limited number of studies on $\mathrm{P}$ uptake and cycling by plankton since the early work of Pomeroy 
(1960) have been largely focused on estuaries and coastal waters (e.g. Taft et al. 1975. Harrison et al. 1977, Krempin et al. 1981, Lebo 1990, Thingstad et al. 1993, 1998, Björkman \& Karl 1994), whereas studies of oceanic communities are still few and largely focused on the Pacific Ocean (Perry 1976, Perry \& Eppley 1981, Harrison 1983, Laws et al. 1984) and the Sargasso Sea (Cotner et al. 1997) The available information suggests that $P$ limitation is particularly important in warm, oligotrophic waters, but the empirical basis on the rates of $\mathrm{P}$ uptake and $\mathrm{P}$ requirements by oceanic plankton communities is still too meager to test this notion. Moreover, most studies report the incorporation of $\mathrm{P}$ into the particulate organic pool, but do not address its possible release to the dissolved organic pool. The dissolved organic matter (DOM) pool is an important reservoir of nutrients and carbon in warm, oligotrophic waters (Vidal et al. 1999). Given the high. rates of phytoplankton carbon (e.g. Karl et al. 1998) and nitrogen (e.g. Bronk et al. 1994) release (often exceeding $50 \%$ of the uptake) to DOM, we hypothesize that phosphorus release as DOM should also encompass a significant fraction of the total phosphate consumed.

Here we report the uptake rate and turnover time of inorganic phosphorus along a latitudinal transect. $\left(27^{\circ} \mathrm{N}\right.$ to $\left.36^{\circ} \mathrm{S}\right)$ across the Central Atlantic Ocean
(Fig. 1). This area is characterised by permanent stratification, which leads to generally low inorganic nutrient concentrations and low plankton biomass in the biogenic zone, with a subsurface (down to $180 \mathrm{~m}$ ) autotrophic biomass maximum (Agustí \& Duarte 1999). However, the doming of the pycnoclines from the equator towards the African coast leads to enhanced nutrient supply and higher plankton biomass (cf. LeBouteiller 1986, Agusti \& Duarte 1999), as can be readily observed from an examination of ocean color (Campbell \& Aarup 1992). Hence, the study comprised a gradient of phytoplankton biomass and nutrient supply, thereby allowing for a greater range in the expected uptake and turnover rates of inorganic phosphorus. We first characterised the nutrient contents of the plankton through bulk measurements of particulate organic $\mathrm{C}, \mathrm{N}$ and $\mathrm{P}$ (POC, PON, and POP). We then conducted tracer $\left({ }^{33} \mathrm{P}-\mathrm{PO}_{4}\right)$ addition experiments in surface and DCM (deep chlorophyll a maximum) waters along the transect to determine the incorporation of dissolved inorganic phosphorus (DIP) into different size fractions $(<0.8 \mu \mathrm{m}$ and $0.8-240 \mu \mathrm{m})$ of particulate organic matter (POM). In addition, we conducted experiments to determine the rate of release of dissolved organic phosphorus (DOP), thereby allowing the estimation of the net production of DOP and the total consumption of DOP.

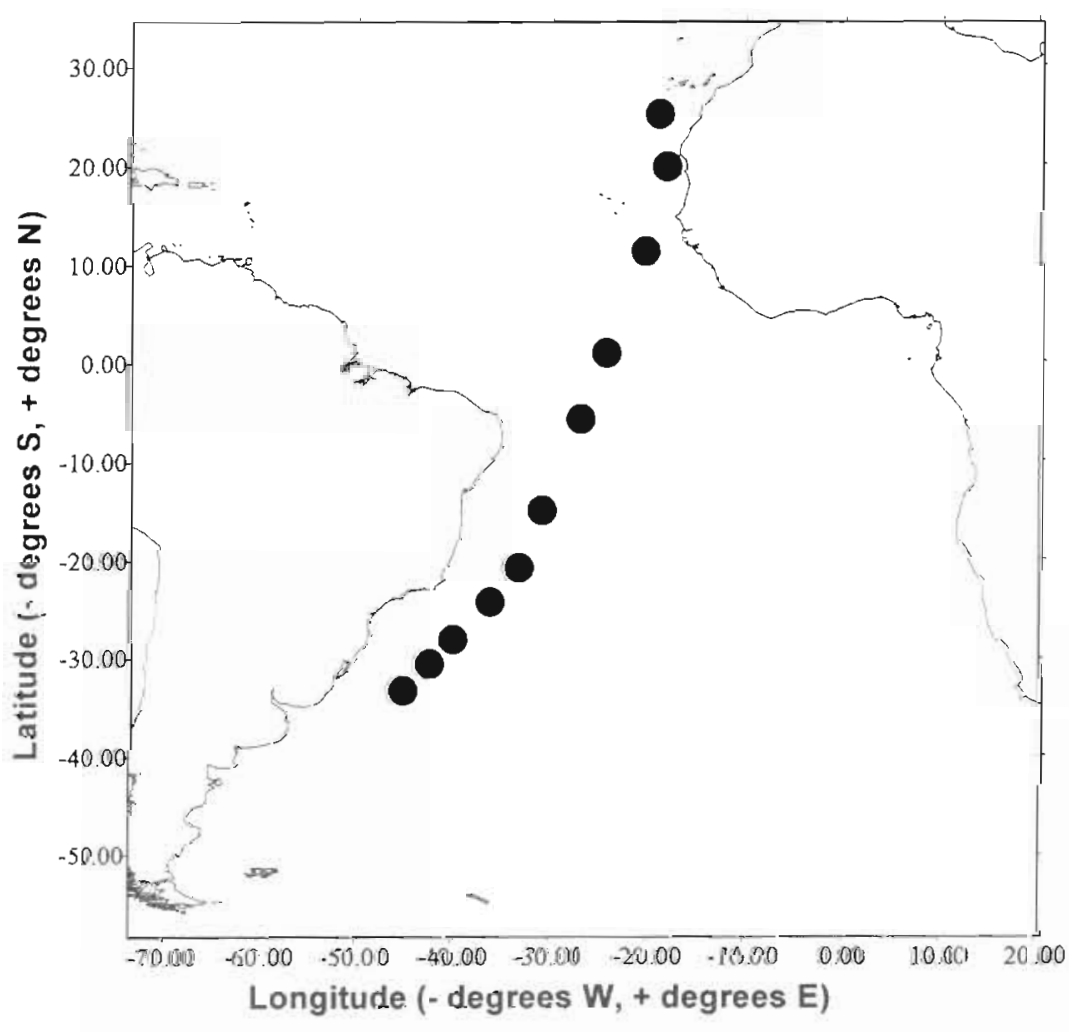

Fig. 1. Stations sampled during the 'Latitud-II' cruise

\section{METHODS}

The present study was conducted from October to November 1995 on board the Spanish RV 'BIO Hespérides' as part of the 'Latitud-II' cruise, which examined latitudinal changes in the control of planktonic production in the Central Atlantic Ocean. A total of 11 stations between the Canary Islands $\left(27^{\circ} 13^{\prime} \mathrm{N}\right)$ and Argentina $\left(36^{\circ} 21^{\prime} \mathrm{S}\right)$ were sampled in this study (Fig 1). Water samples were collected between 06:00 and 10:00 h local time, from the surface and/or the DCM (see Table 1) using 12 to 30 I Niskin bottles mounted on a rosette frame fitted with a CTD profiler Large particles and mesozooplankton were excluded using a $240 \mathrm{~mm}$ Nitex mesh when transferring the seawater into 51 polypropylene bottles.

Four replicate samples (0.5 to 1.5 1) were collected on glass fiber filters (Whatman GF/F) for duplicate measurements of POC, PON and POP in 
the microplankton $(<240 \mu \mathrm{m})$ size fraction. To collect the picoplanktonic fraction $(<0.8 \mu \mathrm{m})$ we first removed larger plankton using a $0.8 \mu \mathrm{m}$ Nucleopore filter (4 replicates), collecting the remaining particles on $\mathrm{GF} / \mathrm{F}$ filters. Duplicate filters of each fraction were analyzed for POC, PON and POP determinations. The filters used for $\mathrm{C}$ and $\mathrm{N}$ analyses were combusted, and those for $\mathrm{P}$ analysis were acid-washed ( $\mathrm{HCl} 10 \%$ ) before use. The samples were preserved frozen until analyzed. POC and PON were measured using a Carlo Erba $\mathrm{CHN}$ analyzer Model 11.04, after removing inorganic carbon with $\mathrm{HCl}$ fumes. POP was determined as soluble reactive $\mathrm{P}$ (SRP) following oxidation of the sample in acidic persulfate at $120^{\circ} \mathrm{C}$ for $30 \mathrm{~min}$ (Koroleff 1983). After oxidation, the sample was filtered through a GF/C filter to remove debris.

Total dissolved phosphorus in the water was determined as SRP following oxidation in acidic persulfate of the filtrate of $20 \mathrm{ml}$ subsamples filtered through $0.2 \mu \mathrm{m}$ membrane filters (Koroleff 1983). Dissolved inorganic P (DIP) was measured directly as SRP (Koroleff 1983). The concentration of DOP was estimated as the difference between total dissolved $\mathrm{P}$ and DIP.

Samples ( $2 \mathrm{ml}$ ) for enumeration of bacteria were preserved with $1.5 \%$ glutaraldehyde. The samples were filtered at low pressure onto black Nuclepore fitters $(0.2 \mu \mathrm{m}$ nominal pore size $)$, and stained with DAPI (4',6-diamino-2-phenylindole) for 5 to $10 \mathrm{~min}$ (Martinussen \& Thingstad 1991). Filters were rinsed with filtered seawater, mounted on glass slides and stored frozen until examination. Bacteria collected on the filters were examined at $1000 \times$ magnification under a Zeiss Axioplan microscope equipped with an epifluorescence unit fitted with a UV Zeiss filter 487701 . The volume of individual bacterial cells was estimated from measurements of the dimensions of 170 cells, using a video camera adapted to the microscope at $1000 \times$, and computing the volume by approximation to the nearest simple geometric shape. The biovolume of phytoplankton (pico- and microautotrophs $>0.2 \mu \mathrm{m}$ ) was derived from epifluorescence counts and size estimates, obtained by examination of 50 to $100 \mathrm{ml} \mathrm{sub}$ samples collected on $0.6 \mu \mathrm{m}$ black Nuclepore filters and illuminated with blue light to high chlorophyll a autofluoresence (Agustí \& Mura unpubl. results). At least 40 cells of bacteria, picoplankton and microphytoplankton were measured to estimate their average cell volume and, when multiplied by their density, their biovolume.

Subsamples $(1.2 \mathrm{ml})$ for counts of Prochlorococcus cells were preserved with $1 \%$ paraformaldehyde + $0.05 \%$ glutaraldehyde (final concentration), frozen in liquid nitrogen and later stored at $-20^{\circ} \mathrm{C}$. The samples were later thawed and run through a Becton \& Dickin- son FACScalibur flow cytometer with laser emission at $488 \mathrm{~nm}$. Samples were run at low speed (approx. $12 \mu \mathrm{l}$ min $^{-1}$ ), and data were acquired in log mode until around 10000 events had been recorded. We added $10 \mathrm{\mu l}$ per sample of a $10^{-5} \mathrm{ml}^{-1}$ solution of yellow-green $0.92 \mu \mathrm{m}$ Polysciences latex beads as an internal standard, to be able to effectively detect Prochlorococcus with a low FL3 (red fluorescence) signal and no FL2 (orange fluorescence) signal. Surface prochlorophytes could not be unambiguously identified because of their low fluorescence. Their concentrations were approximated as being twice the cell density of the population with the highest red fluorescence, following Partensky et al. (1996)

Water samples (1 l) were prefiltered through a $240 \mu \mathrm{m}$ mesh and transferred to acid-washed glass bottles. The incorporation of ${ }^{33} \mathrm{P}_{-} \mathrm{PO}_{4}$ in 2 different size fractions $(>0.2$ and $>0.8 \mu \mathrm{m})$ after the addition of $10 \mu \mathrm{Ci}$ of carrier-free isotope (ICN Biomedicals) was followed by collecting the particulate material in 5 to $10 \mathrm{ml}$ subsamples on Nuclepore filters of 0.2 and $0.8 \mu \mathrm{m}$ pore size, respectively. Sampling frequency decreased progressively, with a total of 8 to 16 samples, depending on uptake velocity, drawn for each experiment. Duplicate samples were drawn whenever sampling intervals exceeded $2 \mathrm{~h}$. The experimental units, enclosed in neutral screens to reduce irradiance to levels approaching those received in situ, were incubated for about $24 \mathrm{~h}$ (range 13 to $46 \mathrm{~h}$ ) in large $\left(1 \mathrm{~m}^{3}\right)$ tanks placed on deck, and continuously flushed with seawater to maintain a constant temperature. A pair of formalin-killed (12.5\% formaldehyde) controls were included with each set of water samples (Ammerman 1993) in order to control for non-biological uptake. Samples for analyses of DOP and DIP concentrations were collected from the experimental bottles at the beginning and end of the experiments. The radioactivity of the particles collected on the filters was assayed in a Beckman LS6000IC scintillation counter with CytoScint ES as scintillation cocktail. A $10 \%$ solution of ethyl acetate was added to the cocktail. The radioactivity of the samples was corrected for the ${ }^{33} \mathrm{P}$ decay with time when the radioactivity measurements of samples from any 1 experiment lasted more than $13 \mathrm{~h}$ (error in the disintegrations per minute $[\mathrm{DPM}] \leq 2.3 \%$ )

The $\mathrm{P}$ incorporated into the $<0.8 \mu \mathrm{m}$ size class was calculated as the difference between the activity retained on the $0.2 \mu \mathrm{m}$. filter and that retained on the $0.8 \mu \mathrm{m}$ filter. The DIP turnover time $(T)$ was determined from the time course of the percent ${ }^{33} \mathrm{P}_{-} \mathrm{PO}_{4}$ incorporated by the organisms (for example Fig, 2). The time course of the percent ${ }^{33} \mathrm{P}_{-} \mathrm{PO}_{4}$ removed showed a rapid initial rate of ${ }^{33} \mathrm{P}_{-} \mathrm{PO}_{4}$ incorporation, which declined over the course of the experiment. The 


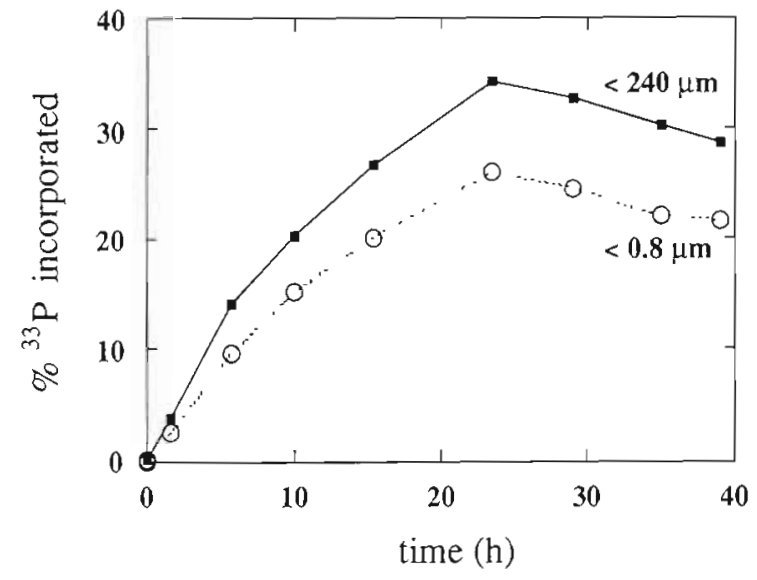

Fig. 2. Time course of the percent of ${ }^{33} \mathrm{P}$ taken up by planktonic organisms $(<240$ and $<0.8 \mu \mathrm{m})$ in surface waters at $33^{\circ} 20^{\prime} \mathrm{S}, 45^{\circ} 20^{\prime} \mathrm{W}$

initial, linear portion of the curve (initial 4 to $10 \mathrm{~h}$ of incubation) was used to fit the equation:

$$
\frac{{ }^{33} P_{t}}{{ }^{33} P_{\mathrm{A}}}=\frac{{ }^{33} P_{0}}{{ }^{33} P_{\mathrm{A}}}+k \cdot t
$$

where ${ }^{33} P_{A}$ is the total ${ }^{33} \mathrm{P}_{-} \mathrm{PO}_{4}$ added, and ${ }^{33} P_{0}$ and ${ }^{33} P_{t}$ are the ${ }^{33} \mathrm{P}_{-} \mathrm{PO}_{4}$ incorporated into particles at time 0 and at time $t$, respectively. The slope of the equation $(k$, $\mathrm{h}^{-1}$ ) provides an estimate of the phosphate turnover rate. The DIP turnover time ( $T$, days) was estimated as the inverse of $k$ (extrapolated to $24 \mathrm{~h}$ ) and the uptake rate of phosphate $\left(V, \mu \mathrm{mol} \mathrm{P} \mathrm{l}^{-1} h^{-1}\right)$ was estimated as the product of the ambient DIP concentration in the water and the phosphate turnover rate. An independent estimate of the net phosphate uptake rate ( $V_{\text {net }}$, $\mu$ mol $\mathrm{P} \mathrm{h}^{-1} \mathrm{l}^{-1}$ ) was calculated from the reduction in DIP between the beginning and end of the experiments. Because the incubation bottles may have contained protozoan grazers, which may have released some of the incorporated $\mathrm{P}$ back to the dissolved pool, $V_{\text {net }}$ represents a minimum estimate of the gross $P$ incorporation rate. The specific uptake rate per unit of particulate phosphorus $\left(U, h^{-1}\right)$ provided an estimate of the turnover rate of POP. In addition, we measured the accumulation of DOP during the course of the experiments at 7 of the stations, providing an estimate of the net rate of DOP release, which, when combined with the estimate of $\mathrm{P}$ uptake into the particulate fraction, provided an estimate of the total phosphate uptake by the community.

The ratio between the turnover rate $(k)$ and the POP within each of the size fractions analyzed was used as an estimate of the affinity for orthophosphate of each fraction. The DIP uptake rate $\left(V, \mu \mathrm{mol} \mathrm{P} \mathrm{h}^{-1} \mathrm{l}^{-1}\right)$ for each size fraction was estimated as the product of $k$ for the respective fractions and the DIP concentration of the water, whereas their P-specific uptake rate $\left(U, h^{-1}\right)$ was estimated as the product of the k:POP ratio and the DIP concentration.

At 3 of the stations, tracer-addition experiments were conducted to provide a rough estimate of the maximum uptake rate $\left(V_{\max }\right)$ of the natural communities, by measuring the initial uptake rate of ${ }^{33} \mathrm{P}$ under saturating concentrations. These experiments differed from those described above in that both $10 \mu \mathrm{Ci}$ of ${ }^{33} \mathrm{P}$ $\mathrm{PO}_{4}$ isotope and unlabeled phosphate $\left({ }^{31} \mathrm{P}\right)$ were added to $1 \mathrm{l}$ of water (prefiltered through a $240 \mu \mathrm{m}$ mesh) to yield a final phosphate concentration of $8 \mu \mathrm{M} \mathrm{PO}_{4}$. Because uptake rates were measured at a high phosphate concentration (phosphate concentration $\gg$ half saturation constant), the uptake rate obtained should approach the maximum uptake rate $\left(U_{\max }\right)$ for the community (Olsen et al. 1989).

\section{RESULTS}

The concentration of DIP in surface waters was rather low, especially in the area between $5^{\circ} \mathrm{S}$ and $36^{\circ} \mathrm{S}$, where the DIP concentration was $<0.2 \mu \mathrm{mol} \mathrm{Pl}^{-1}$ in the upper waters $(<150 \mathrm{~m}$ ) (Fig. 3). Most of the P was

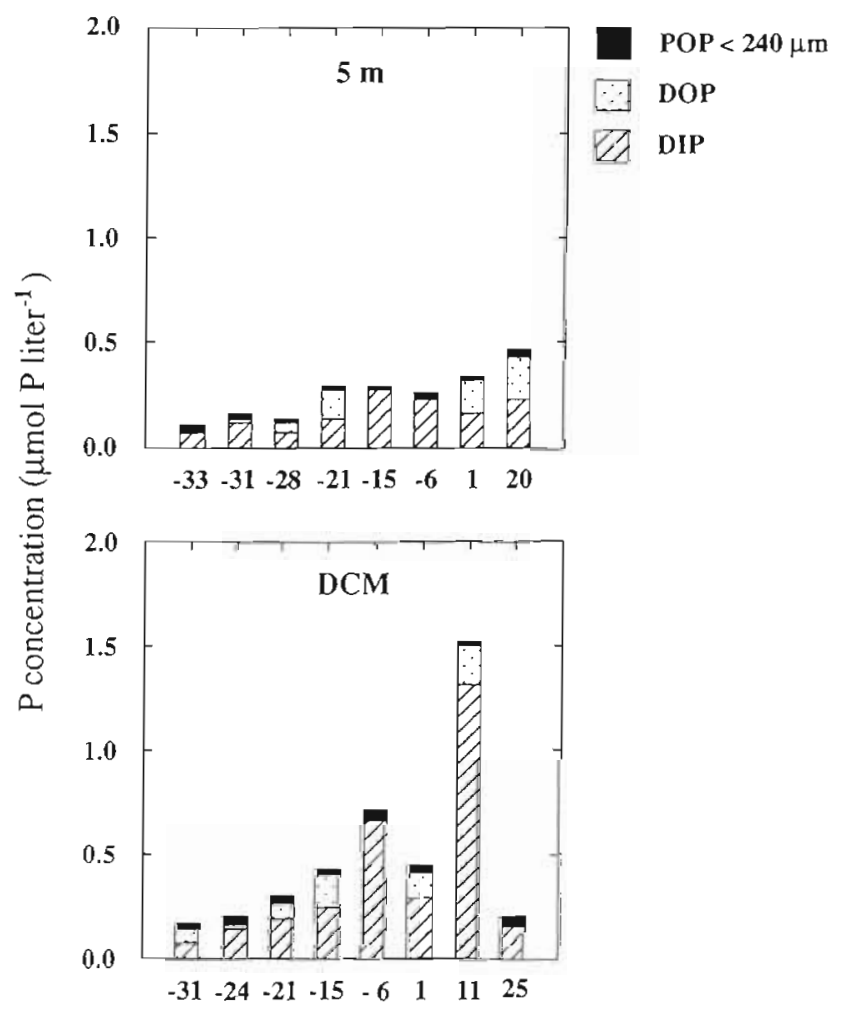

Latitude $(-$ degrees $S,+$ degrees $N$ )

Fig. 3. Latitudinal variation of the partitioning of phosphorus among dissolved organic P (DOP), dissolved inorganic P (DIP) and particulate organic $P$ (POP) $\{240 \mu m$ ) in surface and deep chlorophyll maximum (DCM) waters 
Table 1. Position and depth $(z)$ of the stations for phosphorus uptake experiments, the concentrations of particulate organic $C, N$ and $\mathrm{P}$ (POC, PON and POP), chlorophyli a (chl a), and dissolved inorganic P (DIP) and the biovolume of bacteria and phytoplankton

\begin{tabular}{|c|c|c|c|c|c|c|c|c|c|}
\hline $\begin{array}{c}\text { Lat. } \\
\left({ }^{\circ} \mathrm{N},-^{\circ} \mathrm{S}\right)\end{array}$ & $\begin{array}{l}\text { Long. } \\
\left({ }^{\circ} \mathrm{W}\right)\end{array}$ & $\begin{array}{c}z \\
(\mathrm{~m})\end{array}$ & 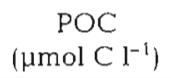 & $\begin{array}{c}\text { PON } \\
\left(\mu \mathrm{mol} \mathrm{N} \mathrm{^{-1 }}\right)\end{array}$ & $\begin{array}{c}\text { POP } \\
\left(\mu \mathrm{mol} \mathrm{P} \mathrm{I}^{-1}\right)\end{array}$ & $\begin{array}{c}\text { Chl a } \\
\left(\mu \mathrm{g} \mathrm{chl} \mathrm{I}^{-1}\right)\end{array}$ & $\begin{array}{c}\text { DIP } \\
\left(\mu \mathrm{mol} \mathrm{P} \mathrm{I}{ }^{-1}\right)\end{array}$ & $\begin{array}{c}\text { Bacteria } \\
\left(10^{3} \mu \mathrm{m}^{3} \mathrm{ml}^{-1}\right)\end{array}$ & $\begin{array}{l}\text { Phytoplanktor } \\
\left(10^{3} \mu \mathrm{m}^{3} \mathrm{ml}^{-1}\right)\end{array}$ \\
\hline 25.2 & 19.1 & 85 & 8.17 & 0.51 & 0.021 & 0.25 & 0.15 & 4.66 & 4.75 \\
\hline 19.8 & 18.3 & 5 & 15.8 & 1.31 & 0.033 & 0.23 & 0.23 & 11.3 & 32.89 \\
\hline 11.3 & 20.4 & 50 & 10.2 & 0.75 & 0.022 & 0.36 & 1.32 & 3.26 & 7.67 \\
\hline 0.95 & 24.4 & 5 & 8.19 & 0.74 & 0.020 & 0.13 & 0.16 & 9.98 & 29.28 \\
\hline 0.95 & 24.4 & 65 & 18.0 & 1.62 & 0.039 & 0.71 & 0.29 & 11.6 & 20.85 \\
\hline-5.72 & 27.1 & 5 & 8.33 & 0.72 & 0.034 & 0.08 & 0.23 & 12.2 & 21.43 \\
\hline-5.72 & 27.1 & 105 & 8.42 & 0.67 & 0.024 & 0.31 & 0.66 & 6.52 & 6.76 \\
\hline-15.0 & 31.0 & 5 & 6.30 & 0.51 & 0.022 & 0.02 & 0.27 & 6.83 & 0.16 \\
\hline-15.0 & 31.0 & 150 & 6.04 & 0.61 & 0.029 & 0.17 & 0.25 & 5.64 & 4.70 \\
\hline-20.8 & 33.4 & 5 & 7.07 & 0.41 & 0.023 & 0.04 & 0.13 & 9.10 & 6.44 \\
\hline-20.8 & 33.4 & 160 & 5.49 & 0.46 & 0.018 & 0.19 & 0.19 & 4.54 & 5.94 \\
\hline-24.3 & 36.4 & 120 & 7.40 & 0.65 & 0.030 & 0.24 & 0.14 & 5.01 & 2.87 \\
\hline-28.1 & 40.1 & 5 & 7.78 & 0.67 & 0.021 & 0.08 & 0.07 & 7.84 & 11.27 \\
\hline-30.6 & 42.5 & 5 & 7.46 & 0.70 & 0.025 & 0.05 & 0.12 & 6.97 & 8.82 \\
\hline-30.6 & 42.5 & 110 & 9.48 & 0.68 & 0.025 & 0.29 & 0.07 & 4.69 & 8.04 \\
\hline-33.3 & 45.3 & 5 & 8.17 & 0.70 & 0.037 & 0.07 & 0.07 & 9.50 & 9.53 \\
\hline
\end{tabular}

in the dissolved pool, with an average of $30.2 \pm$ $7.4 \%$ of the total $\mathrm{P}$ in the surface water being in the dissolved organic pool, and an average of $59.9 \pm 6.9 \%$ of the total $\mathrm{P}$ in the DIP pool. The total P pool at the DCM $\left(0.51 \pm 0.21 \mu \mathrm{mol} \mathrm{P} \mathrm{l^{-1 } )}\right.$ was on average about twice as high as that in

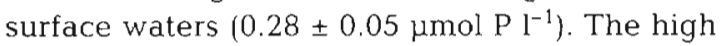
DOP and DIP concentrations observed around $10^{\circ} \mathrm{N}$ (Fig. 3) were ascribed to the proximity to the NW African upwelling (cf. Vidal et al. 1999, Duarte et al. unpubl.).

POC, PON, and POP concentrations differed by about 1 order of magnitude among stations (Table 1). The highest concentrations of POC, PON and POP were found in the surface waters near the upwelling region off NW Africa and in the DCM of the equatorial area, where POC concentrations reached 16 and $18 \mu \mathrm{mol} \mathrm{Cl} \mathrm{Cl}^{-1}$, respectively (Table 1). These maximum concentrations were twice as high as the average POC (average $\pm \mathrm{SE}=8.82 \pm 0.27 \mu \mathrm{mol} \mathrm{Cl^{-1 }}$, which tended to be higher at the DCM, which was found between 50 and $160 \mathrm{~m}$ (Agustí \& Duarte 1999), than in surface waters. The contribution of the 2 size fractions examined $(<0.8$ and $0.8-240 \mu \mathrm{m})$ to the POC, PON and POP concentrations differed considerably. The $0.8-240 \mu \mathrm{m}$ fraction dominated the pools of POC, PON and POP $(76 \%$ of POC, $71 \%$ of PON and POP, on average), except in

Fig. 4. Latitudinal variation of the distribution of $P O C$, PON and POP in the 2 sestonic size fractions examined $(<0.8$ and $0.8-240 \mu \mathrm{m})$ in surface and DCM waters

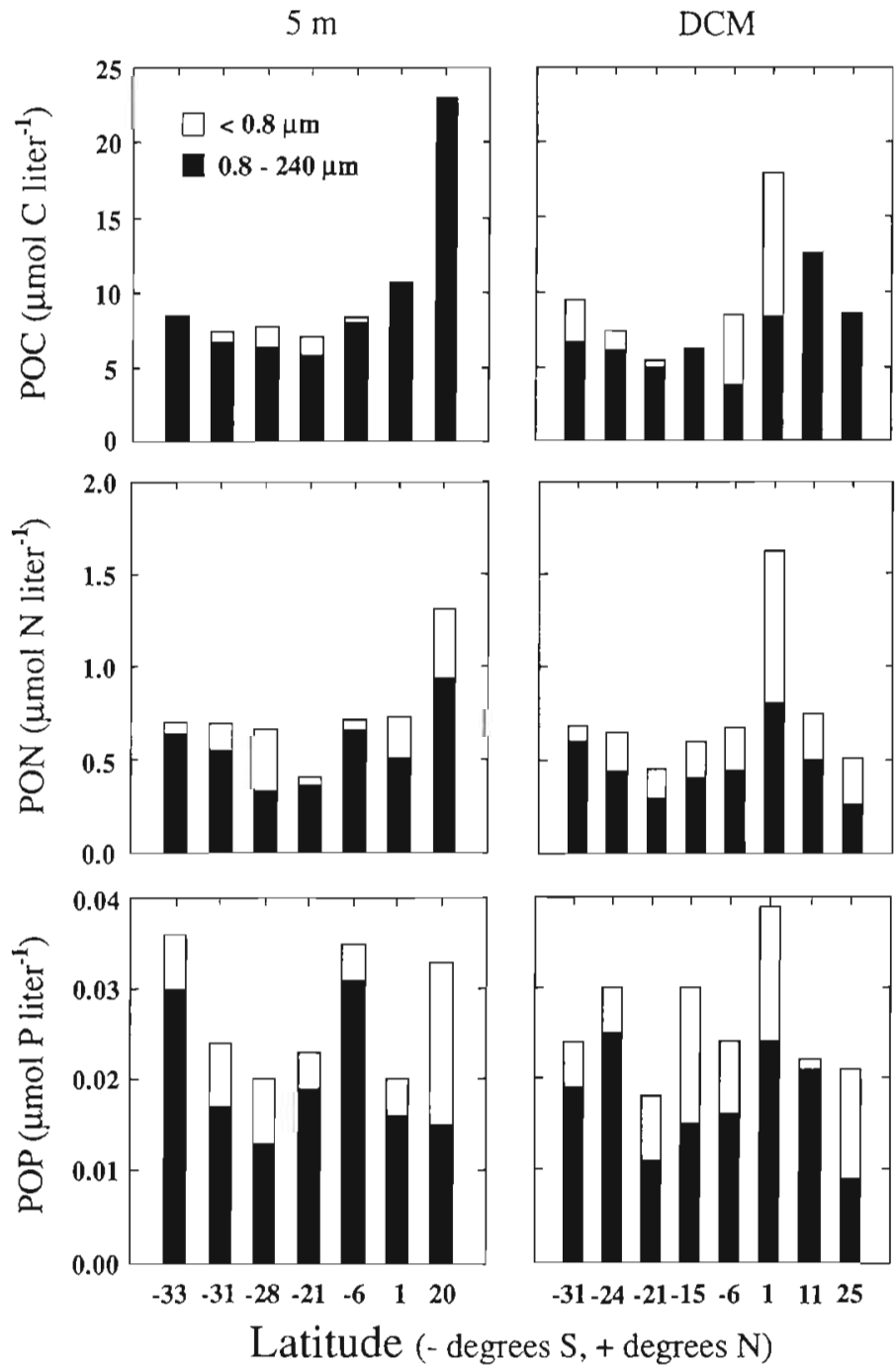


Table 2. Coefficient of determination $\left(\mathrm{r}^{2}\right)$, slope and significance $(\mathrm{p})$ of least-squares, linear regression analyses between the concentrations of particulate organic $C, N$ and $P$ for the total (i.e. $<240 \mu \mathrm{m}$ ) community, and each of the 2 size fractions $(<0.8$ and $0.8-240 \mu \mathrm{m}$ ) considered in surface and DCM waters. The regression slopes provide estimates of the average atomic C:N, C:P and N:P ratios

\begin{tabular}{|c|c|c|c|c|c|c|c|c|c|c|}
\hline & \multirow{2}{*}{$\begin{array}{l}\text { Size fraction } \\
(\mu \mathrm{m})\end{array}$} & \multicolumn{3}{|c|}{ POC versus PON } & \multicolumn{3}{|c|}{$P O C$ versus $P O P$} & \multicolumn{3}{|c|}{ PON versus POP } \\
\hline & & $r^{2}$ & Slope & $\mathrm{p}$ & $r^{2}$ & Slope & $\mathrm{p}$ & $r^{2}$ & Slope & $\mathrm{p}$ \\
\hline \multirow[t]{3}{*}{$5 \mathrm{~m}$} & Total $(<240)$ & 0.9 & 10.7 & 0.001 & 0.2 & 179.5 & 0.36 & 0.2 & 16.5 & 0.35 \\
\hline & $0.8-240$ & 0.7 & 24.7 & 0.017 & 0.1 & $<0$ & 0.59 & 0.1 & 6.2 & 0.63 \\
\hline & $<0.8$ & 0.0 & $<0$ & 0.97 & 0.1 & $<0$ & 0.52 & 0.5 & 18.9 & 0.08 \\
\hline \multirow[t]{3}{*}{ DCM } & Total $(<240)$ & 0.9 & 10.3 & 0.000 & 0.5 & 426.4 & 0.04 & 0.7 & 46.8 & 0.009 \\
\hline & $0.8-240$ & 0.1 & 3.7 & 0.57 & 0.1 & 118.6 & 0.54 & 0.6 & 22.6 & 0.027 \\
\hline & $<0.8$ & 0.7 & 12.3 & 0.012 & 0.2 & 252.1 & 0.35 & 0.3 & 23.1 & 0.19 \\
\hline
\end{tabular}
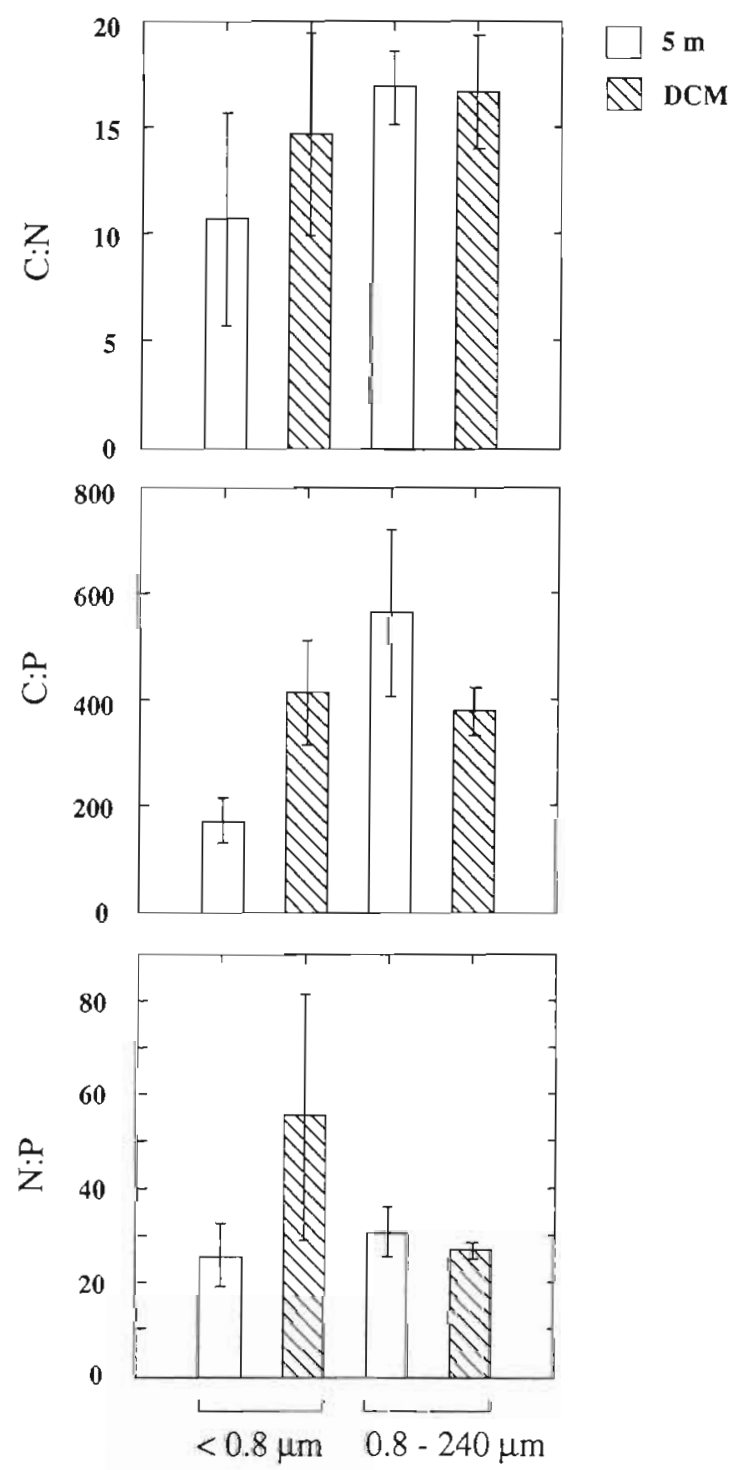

Fig. 5. Average $( \pm \mathrm{SE}) \mathrm{C}: \mathrm{N}, \mathrm{C}: \mathrm{P}$ and $\mathrm{N}: \mathrm{P}$ ratios in the 2 sestonic size fractions examined $(<0.8$ and $0.8-240 \mu \mathrm{m})$ in surface and DCM waters. Sample size for each mean and standard error value $=8$ the DCM near the equator $\left(1^{\circ} \mathrm{S}\right)$, where the fraction $<0.8 \mu \mathrm{m}$ showed an important contribution (Fig. 4).

The biomass of microplankton was evenly distributed between that of autotrophs $(53 \pm 4.8 \%$ of the biovolume, on average) and bacteria ( $46 \pm 4.5 \%$ of the biovolume, on average), although autotrophs clearly dominated the biomass near the NW African upwelling and in DCM waters near the equator (Table 1). The autotrophic biomass was dominated by eukaryotic nanoand microplankton near the NW African upwelling, whereas prochlorophytes and cyanobacteria were significant components of the autotrophic biomass in the most oligotrophic waters, with prochlorophytes representing, on average, $32 \pm 2.1 \%$ of the biovolume across the transect. The size fraction $<0.8 \mu \mathrm{m}$ contained most (70 to $80 \%$ ) of the picoplankters (bacteria, cyanobacteria and prochlorophytes), while the larger fraction also included the nano- and microphytoplankton biomass, as well as heterotrophic protozoa and detrital particles.

The concentrations of POC and PON were closely correlated in both surface and DCM waters (Table 2), and declined from the Canary Islands towards the equator in surface waters, whereas they increased in DCM waters. In contrast, the concentration of POP was rather independent of those of POC and PON, both in the DCM and particularly in surface waters (Table 2), indicative of a highly variable $C: P$ ratio compared to the C:N ratio (Fig. 5). The particulate C:N, C:P and N:P ratios tended to exceed the Redfield ratios. The high values observed for the $C: P$ ratios suggest a high contribution of detrital particles, which are depleted in $\mathrm{P}$ and $N$ relative to $C$ compared to living plankton (e.g. Knauer et al. 1979, Olsen et al. 1986). The size fraction $<0.8 \mu \mathrm{m}$ (which includes bacteria and cyanobacteria) showed the lowest average C:P and N:P ratios, particularly in surface waters (Fig, 5) The C:P ratio of the larger size fraction $(0.8-240 \mu \mathrm{m})$ and the $\mathrm{N}$ :P ratio of the smaller fraction $(<0.8 \mu \mathrm{m})$ were highest at about $30^{\circ} \mathrm{S}$ as well as close to the equator (Fig. 4), indicating the seston of these waters to be P-depleted. 
The phosphate turnover rates $\left(k_{1} \mathrm{~h}^{-1}\right)$ were low, albeit highly variable, ranging from 0.001 to $0.026 \mathrm{~h}^{-1}$. The maximum uptake rate $\left(V_{\max }\right)$ into the particulate fraction of the natural communities, estimated at 3 of the sampling stations, ranged from 0.0001 to $0.0033 \mu \mathrm{mol}$ $\mathrm{Pl}^{-1} \mathrm{~h}^{-1}$, and was comparable to values measured in the carrier-free incubations. This indicates that the uptake rates realized at the in situ phosphate concentrations approach the maximal rates possible. The turnover time of DIP $(T)$ ranged from 1.6 to $40.1 \mathrm{~d}$, and, in surface waters, tended to be fastest at the southern-most stations (Fig. 6), tending to decrease as DIP concentrations
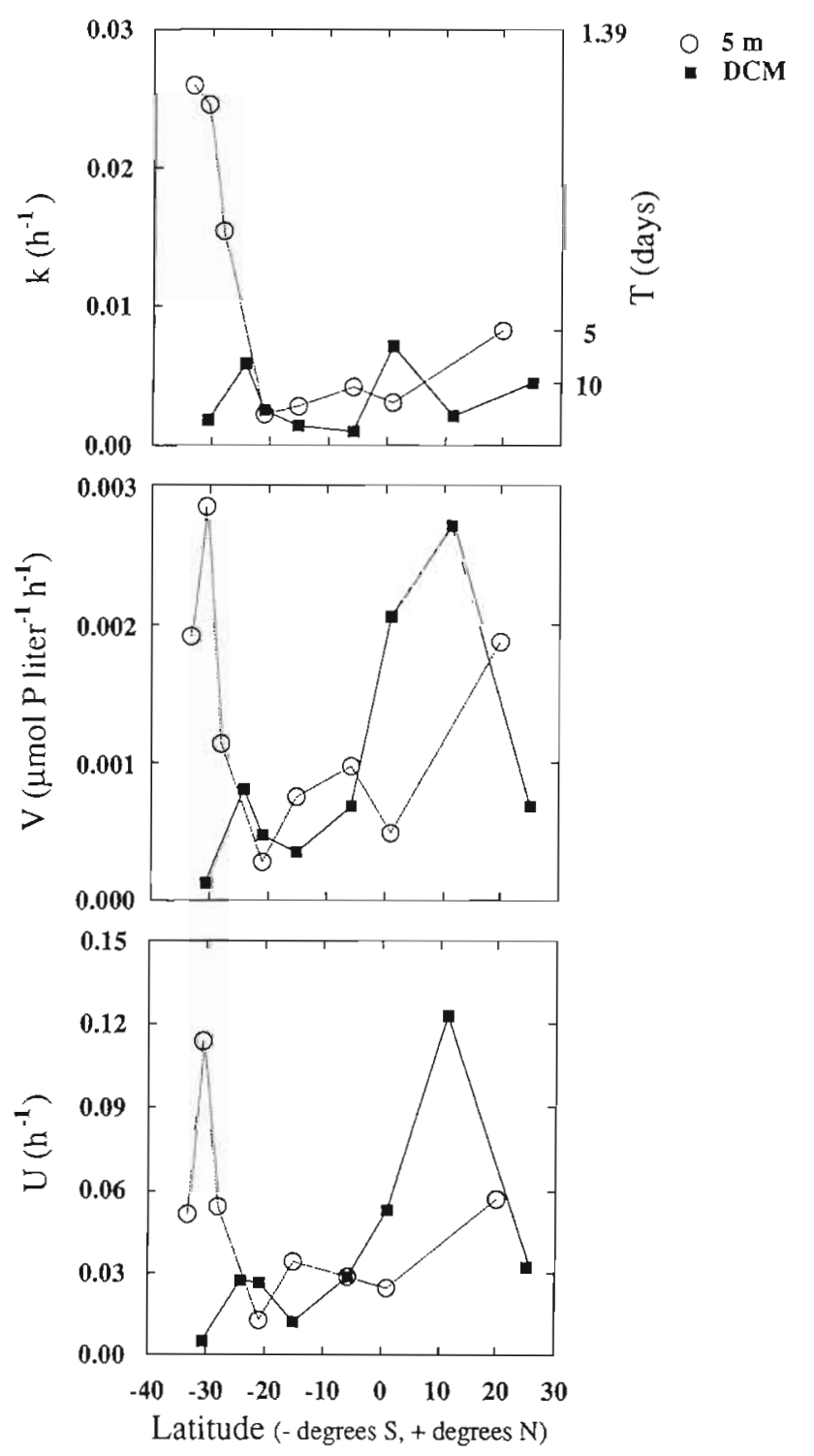

Fig. 6. Latitudinal variation of the uptake rate constant $(k)$, uptake rate $(V)$ and POP turnover rate $(U)$ in surface and DCM waters. The right axis of the top panel shows the DIP turnover time $(T)$, calculated as the inverse of the uptake rate constant declined $(r=0.5, p<0.08)$. The DIP uptake rates into the particulate fraction $(V)$ varied between 0.0001 and $0.028 \mathrm{~mol} \mathrm{P} \mathrm{l}^{-1} \mathrm{~h}^{-1}$ and showed a contrasting latitudinal pattern between surface and DCM waters, involving high $\mathrm{P}$ uptake rates in the surface waters at the southern end of the transect and in the DCM waters off the NW African coast (Fig. 6). The specific uptake rate per unit of particulate phosphorus $(U)$ ranged from 0.005 to $0.12 \mathrm{~h}^{-1}$ and followed a latitudinal pattern that mirrored that of the uptake rate (Fig. 6).

The proportion of isotope accumulated in the particulate fraction by the end of the incubations, which represents a minimum estimate of the total isotope incorporated, was generally low $(<45 \%)$, particularly in DCM waters (mean \pm SE: $8 \pm 2 \%$, Fig. 7). The proportion of isotope accumulated in the particulate fraction was significantly higher (mean \pm SE: $19 \pm 5 \%$ ) in surface waters (Fig. 7). The proportion of isotope accumulated in the particulate fraction decreased from the moderately high values observed at the northern end of the transect $\left(10\right.$ to $\left.25^{\circ} \mathrm{N}\right)$ to the low values between the equator and $20^{\circ} \mathrm{S}$, followed by a considerable

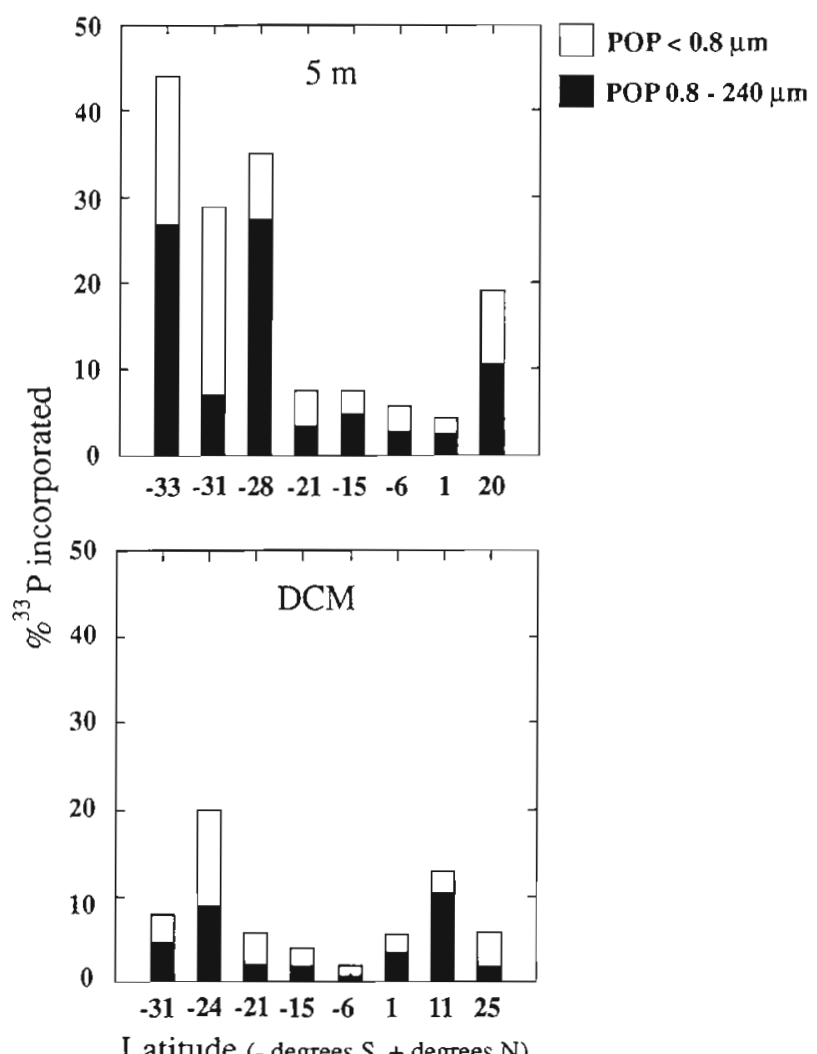

Fig. 7. Latitudinal variation in the proportion of ${ }^{33} \mathrm{P}$ incorporated at steady state (13 to $46 \mathrm{~h}$ ) into the 2 sestonic size fractions examined $(<0.8$ and $0.8-240 \mu \mathrm{m})$ in surface and DCM waters 

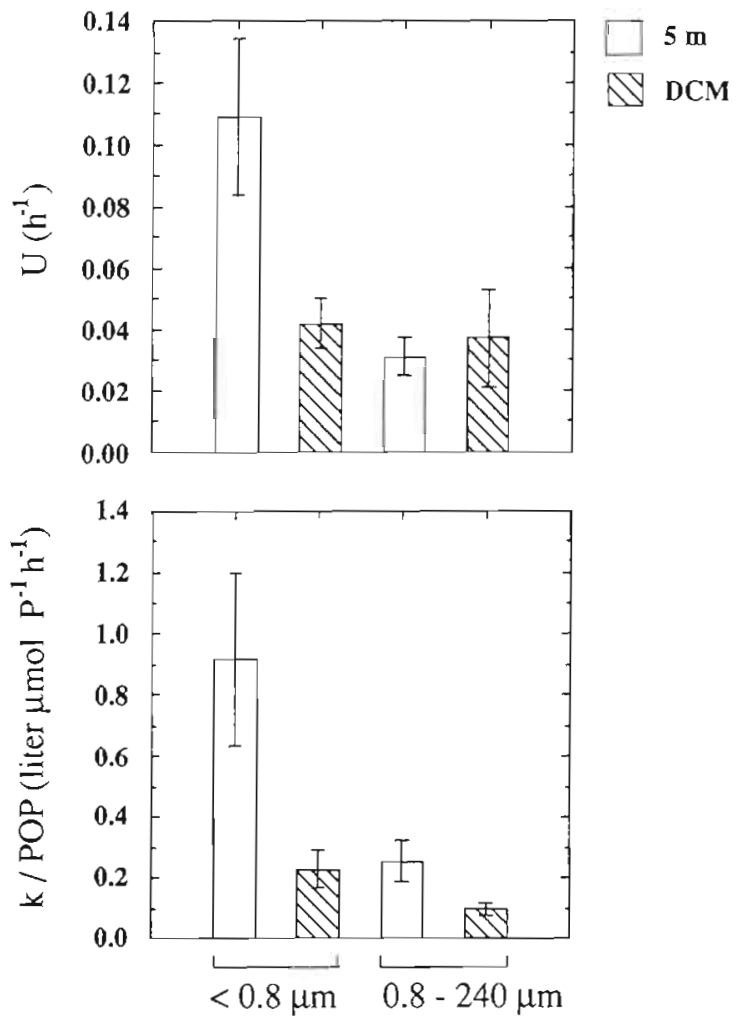

Fig. 8. Average $( \pm S E)$ POP-specific uptake rate $(U)$ and the affinity for $\mathrm{P}(k$ :POP) of the 2 sestonic size fractions examined $(<0.8$ and $0.8-240 \mu \mathrm{m})$ in surface and DCM waters. Sample size for each mean and standard error $=8$

increase towards the southern end of the transect (Fig. 7). The proportion of isotope incorporated increased as the DIP uptake rate increased $(r=0.90, p<$ $0.0001)$. The ${ }^{33} \mathrm{P}$ recovered in the 2 size fractions examined $(<0.8$ and $240-0.8 \mu \mathrm{m})$ was roughly similar at the lowest latitudes, but showed some differences either in surface or DCM waters at the northern and southern ends of the transect (Fig. 7). The size fraction $<0.8 \mu \mathrm{m}$ tended to show a higher specific uptake rate $\left(U, h^{-1}\right)$ and affinity for phosphate ( $k$ :POP ratio, Fig. 8 ) in surface waters than the size fraction $>0.8 \mu \mathrm{m}$ did ( $t$-test, $\mathrm{p}<0.01$ ). Moreover, surface communities tended to show a higher affinity for phosphate than those from the DCM (Fig 8), with a clear tendency for the affinity for phosphate of both fractions to be highest in the surface areas at the southern end of the transect.

The partitioning of $P$ into the different pools (DIP, DOP and POP) changed over the course of the experiments. The concentration of DIP declined by, on average, $44 \%$ during the incubations, yielding a net DIP uptake rate $\left(V_{\text {net }}\right)$ in excess of that calculated from the initial rate of incorporation of ${ }^{33} \mathrm{P}$ into the particulate fraction ( $V$, Fig. 9). This observation suggests a rapid release of ${ }^{33} \mathrm{P}$ to the dissolved pool, as supported by the

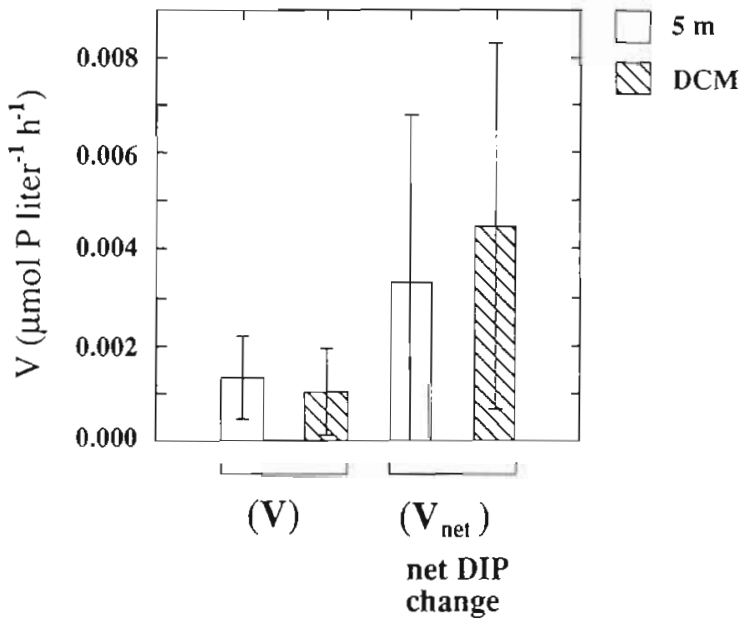

Fig. 9. Comparison of the average $( \pm \mathrm{SE})$ phosphate uptake rate estimated from the initial increase in ${ }^{33} \mathrm{PO}_{4}$ in the particulate fraction $(V)$ and from the reduction in DIP between the beginning and the end of the experiments $\left(V_{\text {net }}\right)$ in surface and DCM waters. Sample size for each mean and standard error $=8$

observation that the DOP concentrations increased greatly (>5-fold) during the incubation in most of the experiments, leading to substantial (mean $\pm \mathrm{SE}=$ $0.0055 \pm 0.002 \mu \mathrm{mol} \mathrm{Pl}^{-1} \mathrm{~h}^{-1}$ ) net DOP production rates. Hence, the sum of the DOP and POP production rates was closely correlated $(r=0.70, p<0.05)$ with our estimates of the net DIP uptake rate, thereby accounting for the loss of DIP during the incubations. The net DOP production rates accounted, on average, for $75 \pm 9.3 \%$ of the total phosphate uptake, and were, on average,

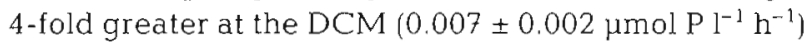
than those in surface waters $\left(0.002 \pm 0.0008 \mu \mathrm{mol} \mathrm{P} \mathrm{l^{-1 }}\right.$ $\mathrm{h}^{-1}$ ), where DIP concentrations, and likely DIP supply, were lower. Indeed, the net DOP production rate increased significantly $(r=0.97, p<0.0001 ; r=0.66$, $p>0.05$ if the experiment at the highest DIP concentration is excluded) with increasing DIP concentration (Fig. 10).

\section{DISCUSSION}

DIP concentrations were low $\left(<0.04 \mu \mathrm{mol} \mathrm{P} \mathrm{I}{ }^{-1}\right)$, but always above the detection limit, in the surface waters along the transect, but DIP concentrations tended to be somewhat higher in DCM waters, which receive the diffusive DIP flux across the thermocline. POP represented a small fraction (17.4\%, on average) of the total $P$ pool and was consequently low; particularly when compared to POC concentrations. The high POC:POP ratios observed $(>200$ ) suggest that detrital particles made an important contribution to POC. Most of the POP was contained in relatively large $(>0.8 \mu \mathrm{m})$ parti- 


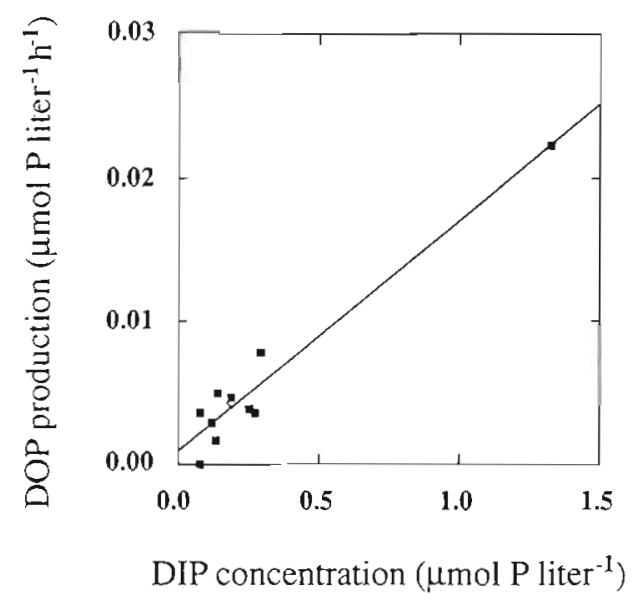

Fig. 10. Relationship between the net rate of DOP production and the DIP concentration in the upper water

cles, but small $(<0.8 \mu \mathrm{m})$ particles had lower C:P ratios, as expected from the importance of bacteria and cyanobacteria, which are characterized by low C:P ratios (Goldman et al. 1987, Vadstein et al. 1988), in this size fraction.

The rates of phosphate incorporation into the particulate fraction were relatively low, resulting in long phosphate turnover times (days), except in the surface waters at the southern end of the transect $\left(25\right.$ to $\left.36^{\circ} \mathrm{S}\right)$. These waters were also characterized by the highest phosphate uptake rates, and the smallest total $P$ pools observed along the transect. The communities north of the equator were characterised by a relatively high biomass of DIP consumers, dominated by nano- and microplankton, and showed a rather high DIP uptake rate. This was in sharp contrast with the communities in the waters in the gyre area south of the equator, which showed the lowest biomass, phosphate uptake rates, and smallest proportion of $\mathrm{P}$ incorporation into the particulate pool. The communities growing in the waters at the southern end of the transect grew under very low phosphate concentrations, but showed high phosphate uptake rates, therefore leading to the fastest phosphate turnover rates observed. The proportion of ${ }^{33} \mathrm{P}$ incorporated into the particulate fraction during experiments was $<45 \%$, and was again greatest at the southern end of the transect. These findings, together with the observations that the communities realized the maximal phosphate uptake rates possible at the in situ phosphate concentrations in the few stations where this was tested experimentally, suggest that the supply of inorganic $P$ was sufficient to meet the demands of the planktonic communities growing in the Central Atlantic. Evidence of P limitation was, however, observed in the P-depleted waters at the southern end of the transect, where P-uptake rates appeared to be limited by $\mathrm{P}$ supply. This suggestion is supported by the observation of a significant alkaline phosphatase activity, which was only detected in the southern-most area $\left(-30^{\circ} \mathrm{S} ; \mathrm{M}\right.$. Vidal unpubl. data)

The smallest $(<0.8 \mu \mathrm{m})$ components of the plankton which dominated the most unproductive waters sampled here, were characterized by higher uptake rates and affinity for phosphate than larger ones, supporting previous conclusions (e.g. Currie \& Kalff 1984, Olsen 1989, Thingstad et al. 1993) that picoplankton are superior competitors for $\mathrm{P}$ than larger plankton. The $k$ :POP ratios measured in Atlantic waters, which provide rough estimates of the affinity for $P$ of the communities, are within the lower range of previously reported estimates (e.g. Currie \& Kalff 1984, Vadstein 1994, Cañellas et al. unpubl.), similar to those characteristic of P-saturated phytoplankton and bacteria (Olsen 1989, Vadstein \& Olsen 1989).

Most analyses of size-fractionated phosphate uptake pointed to heterotrophic bacteria as major players in this process (e.g. Friebele et al. 1978, Berman 1983, Currie \& Kalff 1984, Thingstad et al. 1993, Björkman \& Karl 1994, Dolan et al, 1995). Yet, some reports point to a similar contribution of phytoplankton and bacteria (e.g. Harrison et al. 1977, Krempin et al. 1981) or to a dominant role of phytoplankton (e.g. Lebo 1990, Thingstad et al. 1996) in some areas. Bacterial dominance in $\mathrm{P}$ uptake has been proposed to be characteristic of systems with DIP turnover times much shorter than those observed in Atlantic waters (e.g. Krempin et al. 1981, Lean et al. 1987, Thingstad et al. 1993), whereas a greater contribution of phytoplankton to $P$ uptake is often observed in waters with longer DIP turnover times (e.g. Thingstad et a]. 1996).

The long turnover time and slow phosphate uptake rates generally observed in the Central Atlantic Ocean are in agreement with previous observations in oceanic waters elsewhere (Fig. 11). This suggests that our conclusion that $\mathrm{P}$ is unlikely to be the primary limiting resource for planktonic growth in the Central Atlantic may be applicable to other regions of the open ocean. In contrast, however, estuarine and coastal systems often display short DIP turnover times (e.g. Taft et al. 1975, Thingstad et al. 1993; Fig. 11), although still generally longer than the very fast (minutes) turnover time characteristic of lakes (e.g. Rigler 1956, Lean et al. 1987), which approach those characteristic of strongly P-limited phytoplankton cultures (e.g. Fuhs et al. 1972, Healey 1973, Rivkin \& Swift 1982). Yet, conclusive evidence of $P$ limitation has been derived from the analysis of long-term studies in warm, oligotrophic waters (Michaels et al. 1996, Karl et al. 1997).

Our results suggest that $P$ availability exceeded $P$ demand across most of the Central Atlantic at the time the study was conducted. Whether this situation represents a transient phenomenon or, rather, a consistent 


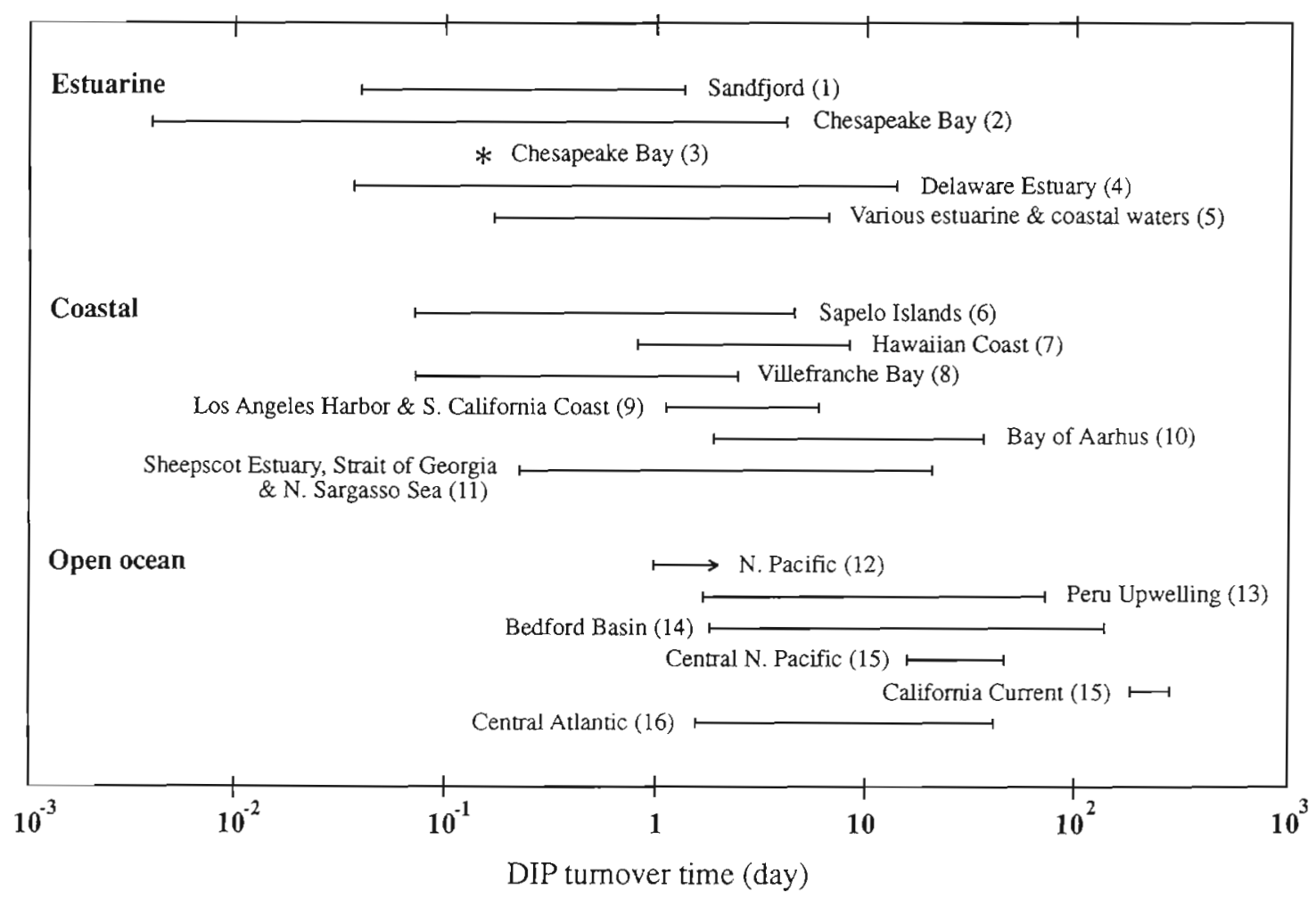

Fig. 11. Turnover rate of dissolved inorganic $P$ in marine systems. (1) Thingstad et al. 1993; (2) Taft et al. 1975; (3) Friebele et al. 1978; (4) Lebo 1990; (5) Pomeroy 1960; (6) Berman 1983; (7) Björkman \& Karl 1994; (8) Dolan et al. 1995; (9) Krempin et al. 1981; (10) Thingstad et al. 1996; (11) Nalewajko \& Lee 1983; (12) Eppley et al. 1973; (13) Harrison et al. 1977; (14) Harrison 1983; (15) Perry \& Eppley 1981; (16) This study. 'Single values, rather than ranges, were available

feature of this area of the ocean cannot be resolved here, as the results presented were derived from a short-term study in which seasonal and interannual variation may be important. Although there are no previous estimates of $\mathrm{P}$ uptake and turnover for the area studied, a similar transect study conducted half a year before the study described here reported evidence of $\mathrm{N}$ limitation of the planktonic community (Planas et al. 1999), consistent with results from previous studies in the region (Le Bouteiller 1986, Metzler et al. 1997). Thus, excess $P$ may be a consistent feature of this region of the ocean. The planktonic organisms take up inorganic $\mathrm{P}$ at considerable rates, but appear to be unable to convert the $P$ incorporated into growth, suggesting an insufficient supply of other nutrients (e.g. N, Fe). This results in the high rates of DOP release, which represent the combined release by the DIP consumers and their microbial grazers, averaging about $75 \%$ of the uptake of DIP and supporting relatively high DOP concentrations in the upper Central Atlantic. These results are consistent with the importance of DOP as an integral component of the P pool in the upper ocean (e.g. Orret \& Karl 1987, Vidal et al. 1999). The importance of DOP release in Central Atlantic waters is comparable to a similarly important release of
DOC and DON, thereby accounting for the large DOM pool accumulating in these waters (Vidal et al. 1999). In contrast, however, the $\mathrm{P}$ released as DOP is then rapidly recycled, as inferred from the high DON:DOP ratio (median ratio 28) in Central Atlantic waters (Vidal et al. 1999), leading to a relatively rapid turnover of the $P$ contained within the plankton in the Central Atlantic as well as a relatively low downward flux of DOP compared to that of DON (Vidal et al. 1999). The planktonic community acts, therefore, as a pump system, mediating the transition between inorganic and organic phosphorus in the dissolved phase. As a result, vertical gradients of DOP concentration in the upper Central Atlantic (cf. Vidal et al. 1999) are not as strong as those reported elsewhere (Coste et al. 1988, Walsh 1989, Bethoux et al. 1992), supporting a modest downwelling flux of $\mathrm{P}$, which accounts for only $9 \%$ of the upward phosphate supply (Vidal et al. 1999). The modest loss of $P$ through the downward flux of DOM is in contrast with the important loss of $\mathrm{N}$ with sinking DOM, which often exceeds the upward nitrate supply (Vidal et al. 1999).

In summary, we conclude that $P$ availability equalled or exceeded planktonic requirements over most of the Central Atlantic at the time of the study, except for the 
southern end of the transect, where some evidence of $P$ limitation was detected. The results support, when combined with other estimates available in the literature, the existence of a general trend towards a reduction in the importance of $P$ as a limiting nutrient from freshwaters to the open ocean. Despite this situation, the high efficiency for $\mathrm{P}$ uptake by the pico-sized organisms dominating planktonic communities in the oligotrophic waters studied here allows them to play a major role in the geochemical processes involving $P$. The excess $\mathrm{P}$ relative to requirements fuels a luxury $\mathrm{P}$ uptake by the planktonic community in the oligotrophic waters studied here, leading, together with grazer-mediated release, to a rapid transformation of inorganic $\mathrm{P}$ into DOP, thereby minimizing $\mathrm{P}$ losses from the biogenic layer.

Acknowledgements. This is a contribution to the project 'Latitud' funded by the Spanish Interministerial Commission for Science and Technology (CICYT, grant no. AMB94-0739). We are grateful to Mario Mannquez and Pedro Jornet for assistance with CTD profiling, Pep Gasol, Anna Lucea and Montse Vidal for providing unpublished data and help with chemical analyses, and Olav Vadstein for useful comments on the manuscript

\section{LITERATURE CITED}

Agustí S, Duarte CM (1999) Phytoplankton chlorophyll a distribution and water column stability in the Central Atlantic Ocean. Oceanol Acta 22:193-203

Ammerman JW (1993) Microbial cycling of inorganic and organic phosphorus in the water column. In: Kemp PF, Sherr BF, Sherr EB, Cole JJ (eds) Handbook of methods in aquatic microbial ecology. Lewis Publishers, Boca Raton, FL, p 649-660

Berman T (1983) Phosphorus uptake by microplankton in estuarine and coastal shelf waters near Sapelo Island, Georgia, U.S.A. Estuaries 6:160-166

Bethoux JP, Morin P, Madec C, Gentili C (1992) Phosphorus and nitrogen behaviour in the Mediterranean Sea. DeepSea Res 39:1641-1654

Bjorkman K, Karl DM (1994) Bioavailability of inorganic and organic phosphorus compounds to natural assemblages of microorganisms in Hawaiian coastal waters. Mar Ecol Prog Ser 111:265-273

Bratbak G, Thingstad TF (1985) Phytoplankton-bacteria interactions: an apparent paradox? Analysis of a model system with both competition and commensalism. Mar Ecol Prog Ser 25:23-30

Broecker WS (1982) Ocean chemistry during glacial time. Geochim Cosmochim Acta 46:1689-1705

Bronk DA, Glibert PM, Ward BB (1994) Nitrogen uptake, dissolved organic nitrogen release, and new production. $\mathrm{S}_{\mathrm{Ci}}$ ence 265:1843-1846

Campbell JW, Aarup T (1992) New production in the North Atlantic derived from seasonal patterns of surface chlorophyll. Deep-Sea Res 39:1669-1694

Carpenter EJ, Capone DG (1983) Nitrogen in the marine environment. Academic Press, New York

Coste B, Le Corre P, Minas HJ (1988) Re-evaluation of the nutrient exchanges in the Strait of Gibraltar. Deep-Sea Res 35:767-775

Cotner JB, Ammerman JW, Peele ER, Bentzen E (1997) Phosphorus-limited bacterioplankton growth in the Sargasso Sea. Aquat Microb Ecol 13:141-149

Currie DJ, Kalff J (1984) A comparison of the abilities of freshwater algae and bacteria to acquire and retain phosphorus. Limnol Oceanogr 29:298-310

Dolan JR, Thingstad TF, Rassoulzadegan F (1995) Phosphate transfer between microbial size-fractionations in Villefranche Bay (N.W. Mediterranean Sea), France in autumn 1992. Ophelia 41:71-85

Downing JA, Osendberg CW, Sarnelle O (1999) Meta-analysis of marine nutrient-enrichment experiments: variation in the magnitude of nutrient limitation. Ecology 80 : 1157-1167

Eppley RW, Renger EH, Venrick EL, Mullin MM (1973) A study of plankton dynamics and nutrient cycling in the central gyre of the North Pacific Ocean. Limnol Oceanogr 18:534-551

Friebele ES, Correll DL, Faust MA (1978) Relationship between phytoplankton cell size and the rate of orthophosphate uptake: in situ observations of an estuarine population. Mar Biol 45:39-52

Fuhs GW, Demerle SD, Canelli E, Chen M (1972) Characterization of phosphorus-limited algae. Am Soc Limnol Oceanogr Spec Symp 1:113-132

Gasol JM, del Giorgio PD, Duarte CM (1997) Biomass distribution in marine planktonic communities. Limnol Oceanogr 43:1353-1363

Goldman JC, Caron DA, Dennet MR (1987) Regulation of gross growth efficiency and ammonium regeneration in bacteria by substrate C:N ratio. Limnol Oceanogr 32 : $1239-1252$

Harrison WG (1983) Uptake and recycling of soluble reactive phosphorus by marine microplankton. Mar Ecol Prog Ser 10:127-135

Harrison WG, Azam F, Renger EH, Eppely RW (1977) Some experiments on phosphate assimilation by coastal marine plankton. Mar Biol 40:9-18

Healey FP (1973) Inorganic nutrient uptake and deficiency in algae. CRC Crit Rev Microbiol 3:69-113

Karl DM, Letelier R, Tupas L, Dore J, Christian J, Hebel D (1997) The role of nitrogen fixation in biogeochemical cycling in the subtropical North Pacific Ocean. Nature 388:533-538

Karl DM, Hebel DV, Björkman K, Letelier RM (1998) The role of dissolved organic matter release in the productivity of the oligotrophic North Pacific Ocean. Limnol Oceanogr 43:1270-1286

Knauer GA, Martin JH, Bruland KW (1979) Fluxes of particulate carbon, nitrogen and phosphorus in the upper water column of the northeast Pacific. Deep-Sea Res 26:97-108

Koroleff F (1983) Determination of phosphorus. In: Grasshoff K, Ehrhardt M, Kremlin K (eds) Methods of seawater analysis, 2nd edn. Verlag Chemie, Weinheim, p 125-139

Krempin DW, Mcgrath SM, Beeler Soohoo SM, Sullivan CW (1981) Orthophosphate uptake by phytoplankton and bacterioplankton from the Los Angeles Harbor and Southern California coastal waters. Mar Biol 64:23-33

Laws EA, Redalle DG, Haas LW, Bienfang PK, Eppley RW, Harrison WG, Karl DM, Mara J (1984) High phytoplankton growth and production rates in oligotrophic Hawaiian coastal waters. Limnol Oceanogr 29:1161-1169

Lean DRS, Abbott AA, Pick FR (1987) Phosphorus deficiency of Lake Ontario plankton. Can J Fish Aquat Sci 44: 2069-2076 
Lebo ME (1990) Phosphate uptake along a coastal plain estuary. Limnol Oceanogr 35:1279-1289

LeBouteiller A (1986) Environment control of nitrate and ammonium uptake by phytoplankton in the Equatorial Atlantic Ocean. Mar Ecol Prog Ser 30:167-179

Martinussen I. Thingstad TF (1991) A simple double staining technique for simultaneous quantification of auto- and heterotrophic nano- and picoplankton. Mar Microb Food Webs 5:5-11

Metzler PM, Glibert PM, Gaeta S, Ludlam M (1997) New and regenerated production in the South Atlantic off Brazil. Deep-Sea Res 44:363-384

Michaels AF, Olson D, Sarmiento JL, Ammerman JW, Fanning $K$, Jahnke R, Knap AH, Lipschultz F, Prospero JM (1996) Inputs, losses and transformations of nitrogen and phosphorus in the deep North Atlantic Ocean. Biogeochemistry 35:181-226

Nalewajko C, Lee K (1983) Light stimulation of phosphate uptake in marine phytoplankton. Mar Biol 74:9-15

Olsen Y (1989) Evaluation of competitive ability of Staurastrum luetkemullerii (Chlorophyceae) and Microcystis aeruginosa (Cyanophycae) under P limitation. J Phycol $25: 486-499$

Olsen $Y$, Jensen A, Reiertsen $H$, Borsheim KY, Heldal $M$, Langeland A (1986) Dependence of the rate of release of phosphorus by zooplankton on the $\mathrm{P}: \mathrm{C}$ ratio in the food supply, as calculated by a recycling model. Limnol Oceanogr 31:34-44

Olsen Y, Vadstein O, Andersen T, Jensen A (1989) Competition between Staurastrum Iuetkemullerii (Chlorophyceae) and Microcystis aeruginosa (Cyanophycae) under varying modes of phosphate supply. J Phycol 25:499-508

Orret K, Karl DM (1987) Dissolved organic phosphorus production in surface seawaters. Limnol Oceanogr 32: $383-395$

Partensky F, Blanchot J, Lantoine F, Neveux J, Marie D (1996) Vertical structure of phytoplankton at different trophic sites of the tropical northeastern Atlantic Ocean. DeepSea Res I 43:1191-1213

Perry MJ (1976) Phosphate utilisation by an oceanic diatom in phosphorus-limited chemostat culture and in the oligotrophic waters of the central North Pacific. Limnol Oceanogr 21:88-107

Perry MJ. Eppley RW (1981) Phosphate uptake by phytoplankton in the central North Pacific Ocean. Deep-Sea Res 28:39-49

Planas D, Agusti S, Duarte CM, Granata TC, Merino M (1999) Nitrate uptake and diffusive nitrate supply in the Central Atlantic. Limnol Oceanogr 44:116-126

Editorial responsibility: Otto Kinne (Editor),

Oldendorf/Luhe, Germany
Pomeroy LR (1960) Residence time of dissolved phosphate in natural waters. Science 131:1731-1732

Redfield AC (1958) The biological control of chemical factors in the environment. Am Sci 46:205-222

Rigler FH (1956) A tracer study of the phosphorus cycle in the lake water. Ecology 37:550-562

Rivkin RB, Anderson MR (1997) lnorganic nutrient limitation of oceanic bacterioplankton. Limnol Oceanogr 42:730-740

Rivkin RB. Swift E (1982) Phosphate uptake by the oceanic dinoflagellate Pyrocystis noctiluca. J Phycol 18:113-120

Smith SV (1984) Phosphorus versus nitrogen limitation in marine environment. Limnol Oceanogr 29:1149-1160

Taft JL, Taylor WR, McCarthy JJ (1975) Uptake and release of phosphorus by phytoplankton in the Chesapeake Bay Estuary, USA. Mar Biol 33:21-32

Thingstad FT, Rassoulzadegan F (1995) Nutrient limitations, microbial food webs, and 'biological C-pumps': suggested interactions in a P-limited Mediterranean. Mar Ecol Prog Ser 117:299-306

Thingstad FT, Skjoldal EF, Bohne RA (1993) Phosphorus cycling and algal-bacterial competition in Sandsfjord, western Norway. Mar Ecol Prog Ser 99:239-259

Thingstad FT, Riemann B, Havskum H, Garde K (1996) Incorporation rates and biomass content of $\mathrm{C}$ and $\mathrm{P}$ in phytoplankton and bacteria in the Bay of Aarhus (Denmark) June 1992. J Plankton Res 18:97-121

Thingstad FT, Zweifel UL, Rassoulzadegan F (1998) P limitation of heterotrophic bacteria and phytoplankton in the Northwest Mediterranean. Limnol Oceanogr 43:88-94

Vadstein O (1994) The role of heterotrophic, planktonic bacteria in the cycling of phosphorus in lakes: phosphorus requirements, competitive ability and food web interactions. Dr philos thesis, University of Trondheim

Vadstein O, Olsen Y (1989) Chemical composition and phosphate uptake kinetics of limnetic bacterial communities cultured in chemostats under phosphorus limitation. Limnol Oceanogr 34:939-94.6

Vadstein O, Jensen A, Olsen Y, Reinertsen (1988) Growth and phosphorus status of limnetic phytoplankton and bacteria. Limnol Oceanogr 33:489-503

Vadstein O, Jensen A, Olsen Y, Reinertsen H (1993) The role of planktonic bacteria in phosphorus cycling in lakessink and link. Limnol Oceanogr 38:1539-1544

Vidal M, Duarte CM, Agustí S (1999) Dissolved organic nitrogen and phosphorus pools and fluxes in the Central Atlantic Ocean. Limnol Oceanogr 44:106-115

Walsh TW (1989) Total dissolved nitrogen in seawater: a new high temperature combustion method and a comparison with photo-oxidation. Mar Chem 26:295-311

Submitted: March 23, 1999; Accepted: September 13, 1999 Proofs received from author(s): February 25, 2000 